\title{
Effect of processing on antioxidant potential and total phenolics content in beet (Beta vulgaris $\mathrm{L}$.)
}

\author{
Efeito do processamento no potencial antioxidante e conteúdo \\ de fenólicos totais de beterraba (Beta vulgaris L.)
}

\section{Dorivaldo da Silva RAUPP ${ }^{1 *}$, Eliseu RODRIGUES ${ }^{2}$, Ismael Ivan ROCKENBACH ${ }^{2}$, Aline CARBONAR ${ }^{1}$, Priscilla Faber de CAMPOS ${ }^{1}$, Aurélio Vinicius BORSATO ${ }^{3}$, Roseane FETT ${ }^{2}$}

\begin{abstract}
The antioxidant capacity of beet is associated with non-nutritive constituents, such as phenolic compounds. The purpose of this research was to evaluate the effect of two different heat-processing techniques (drying and canned) on the antioxidant potential (ABTS) and phenolics content of beets. A forced air circulation dehydrator was used for the drying. Drying at high temperatures $\left(100+90{ }^{\circ} \mathrm{C} / 5.6\right.$ hours; $90{ }^{\circ} \mathrm{C} / 6$ hours $)$ increased the antioxidant potential of the processed products while mild drying conditions decreased it $\left(80^{\circ} \mathrm{C} / 6\right.$ hours; $100+70{ }^{\circ} \mathrm{C} / 6$ hours $)$ or had no effect on it $\left(70^{\circ} \mathrm{C} / 7\right.$ hours; $100+80^{\circ} \mathrm{C} / 6$ hours $)$. For the canned products, the antioxidant potential did not differ according to the $\mathrm{pH}$ (4.2 to 3.8) for any of the four acids tested. Some processing methods influenced the antioxidant potential of the processed products, and this was also dependent on changes in the total phenolics content.
\end{abstract}

Keywords: Beta vulgaris; beet; antioxidant activity; phenolic compounds.

\section{Resumo}

O potencial antioxidante da beterraba está associado com seus constituintes não nutritivos, como os compostos fenólicos. A proposta da pesquisa foi avaliar o efeito de duas diferentes técnicas de processos (secagem e processamento de conservas) sobre o potencial antioxidante (ABTS) e o conteúdo de fenólicos de beterraba. Foi usado um secador de circulação forçada de ar para a secagem. Secagem em altas temperaturas $\left(100+90^{\circ} \mathrm{C} / 5,6\right.$ horas; $90^{\circ} \mathrm{C} / 6$ horas $)$ aumentaram o potencial antioxidante dos produtos processados, enquanto que condições brandas, comparativamente, diminuíram $\left(80^{\circ} \mathrm{C} / 6\right.$ horas; $100+70{ }^{\circ} \mathrm{C} / 6$ horas) ou não tiveram efeito $\left(70{ }^{\circ} \mathrm{C} / 7\right.$ horas; $100+80{ }^{\circ} \mathrm{C} / 6$ horas $)$. Nos processos de conservas, o potencial antioxidante não diferiu com a variação de $\mathrm{pH}(4,2$ to 3,8$)$, para qualquer dos quatro ingredientes acídicos testados. Alguns métodos de processamento interferiram no potencial antioxidante dos produtos obtidos, e isso dependeu também de mudanças no conteúdo fenólico total.

Palavras-chave: Beta vulgaris; beterraba; atividade antioxidante; compostos fenólicos.

\section{Introduction}

Antioxidants present in fruits and vegetables have been associated with reduced risk of cardiovascular diseases and various forms of cancer (KAUR; KAPOOR, 2001; LAJOLO, 2005; YANG et al., 2001). These benefits have led to research studies in order to find antioxidants in plant material mainly used as foods (APARICIO-FERNANDEZ et al., 2005; GARCÍA-ALONSO et al., 2004; MOYER et al., 2002; ROESLER et al., 2007; YANG; GUO; YUAN, 2008; WU et al., 2004).

Among the compounds with antioxidant properties are the phenolics, which are believed to act as antioxidant, anti-carcinogenic, anti-microbial, anti-allergic, anti-mutagenic and anti-inflammatory, as well as in the reduction of cardiovascular diseases (KIM; JEONG; LEE, 2003; VALI et al., 2007; YANG; GUO; YUAN, 2008; YANG, et al., 2001). Phenolics occur naturally in plants and are present in fruits, vegetables, leaves, nuts, seeds and flowers; therefore, they are present in the human diet, but are also used in some medicinal preparations (MOYER et al., 2002; PRIOR et al., 1998; TROUNG et al., 2004). Factors that can influence the antioxidant potential of plants include genotype, environmental and climate conditions, season of growth, soil type, geographic location, plant diseases, storage conditions and processing conditions (BOATENG et al., 2008; MADRAU et al., 2008; PADDA; PICHA, 2008; SCALZO et al., 2005; WANG; ZHENG; GALLETTA, 2002).

Beet (Beta vulgaris) is widely cultivated for the production of commercial sugar, forage plants, natural dye and food for human consumption. The extracts used as a natural colorant for food products have been shown to possess effective antioxidant properties, reducing lipid oxidation in cooked pork (MORNEMENT, 2002; NILSON, 1970; REY et al., 2005). The antioxidant capacity of beet has been associated with the constitutive presence of phenolic compounds, which allow

${ }^{1}$ Departamento de Engenharia de Alimentos, Universidade Estadual de Ponta Grossa - UEPG, CEP 84030-900, Ponta Grossa, PR, Brasil, e-mail: dsraupp@pq.cnpq.br

2 Departamento de Ciência e Tecnologia de Alimentos, Universidade Federal de Santa Catarina - UFSC, CEP 88034-001, Florianópolis, SC, Brasil

${ }^{3}$ Embrapa - Pantanal, CEP 79320-900, Corumbá, MS, Brasil

${ }^{*}$ Corresponding author 
nutraceutical benefits in the promotion of the human health and in the prevention of degenerative diseases and cancer (RICE-EVANS; MILLER; PAGANGA, 1996; VALI et al., 2007; YANG; GUO; YUAN, 2008; YANG et al., 2001).

The effect of drying and acidic canned processing on the total phenolics content and antioxidant activity of beet is not clearly explained yet. Therefore, the aim of this study was to investigate the effect of two different heat-processing techniques (drying and canned) on the antioxidant potential and phenolics content found in raw beet (cv. Early wonder) pulp, the leading beet cultivar grown in Brazil.

\section{Materials and methods}

\subsection{Raw beet}

Fresh raw beet (Beta vulgaris L.) cv. Early wonder was used for the processing of dried chip-type beet products and acidic canned beet products.

\subsection{Processing of dried chip-type beet products}

The design was randomized containing six treatments (drying process conditions) and five repetitions. The following temperature conditions were used: $70{ }^{\circ} \mathrm{C} / 7$ hours; $80^{\circ} \mathrm{C} / 6$ hours; $90{ }^{\circ} \mathrm{C} / 6$ hours; $100+70{ }^{\circ} \mathrm{C} / 6$ hours; $100+80{ }^{\circ} \mathrm{C} / 6$ hours or $100+90^{\circ} \mathrm{C} / 5.6$ hours.

Fresh raw beets, approximately $3 \mathrm{~kg}$, after being washed in water, were cooked for 30 minutes in boiling water. The beets were cooled, peeled and sliced in cross sections (approximately $2 \mathrm{~mm}$ thick). The slices, after being soaked in brine bath $(\mathrm{NaCl} 4 \%, \mathrm{~m} / \mathrm{m})$ for 30 minutes, were ready for drying in the forced air circulation dryer $(90 \times 80 \mathrm{~cm})$. The drying temperature was adjusted differently for each treatment. The temperature of $100{ }^{\circ} \mathrm{C}$ was applied for 1 hour. Once a constant weight was observed, the beet slices on each tray were removed from the dryer and cooled to room temperature $\left(25^{\circ} \pm 5^{\circ} \mathrm{C}\right)$. The dried beet slices were placed on plastic (polyethylene) and kept at room temperature for 24 hours to stabilize the internal moisture, and then stored in freezer $\left(-18^{\circ} \mathrm{C}\right)$ until the time of analysis.

\subsection{Processing of acidic canned beet products}

The construction of the experiment was randomized using four acidic ingredients (citric acid, lactic acid, acetic acid, and vinegar from ethyl alcohol) and five levels of $\mathrm{pH}(4.2,4.1,4.0$, $3.9,3.8$ ), totalizing 20 treatments (conditions for processing), all carried out with four replicates.

The fresh raw beets were processed in batches of $21 \mathrm{~kg}$ for each type of acid used. After being washed in water, they were cooked for 30 minutes in boiling water, according to industrial recommendations. The beets were cooled, peeled and sliced into cross-sections (7-10 $\mathrm{mm}$ thick). An average weight of $350 \mathrm{~g}$ of beet slices was placed in glass jars, and acidic brine containing $\mathrm{NaCl} 40$ g.L $\mathrm{L}^{-1}$ was added, followed by heat treatment for 40 minutes in boiling water, as currently used in the canned beet industry. The cooling after the heat treatment was carried out using water at room temperature.

\subsection{Phenolic compounds and antioxidant activity}

\section{Reagents}

The reagent 2,2'-azino-bis(3-ethylbenzthiazoline-6-sulfonic acid) (ABTS), Trolox (6- hydroxy-2,5,7,8-tetramethylchroman2 -carboxylic acid) and gallic acid were purchased from Sigma-Aldrich Chemie (Steinheim, Germany). The Folin-Ciocalteau reagent, 2,4,6-tri (2-pyridyl)-s-triazine (TPTZ) and polyoxyethylene sorbitan monopalmitate (Tween 40) were purchased from Fluka Chemie AG (Buchs, Switzerland). The reagents methanol, sodium carbonate, sodium hydroxide and potassium persulfate were purchased from Vetec (São Paulo, Brazil).

\section{Determination of beet dry mass}

The dry mass (raw and processed) of the beet samples was obtained by placing them in oven at $105^{\circ} \mathrm{C}$, until constant weight (ASSOCIATION..., 1995), and calculating their contents ratios based on the total weight of the samples. The results were used to express the antioxidant activity and total phenolics content on a dry weight basis (dwb).

\section{Preparation of extracts}

Samples ( $3.0 \mathrm{~g}$ ) of raw beet and the canned beet products were ground to a fine powder (particle size $<0.5 \mathrm{~mm}$ ) and extracted with $15 \mathrm{~mL}$ of chilled aqueous methanol (methanol:water, 80:20 v/v), using ultrasonic treatment (Unique equipment USC-1400, Florianopolis, Brazil) for 30 minutes at room temperature. The mixture obtained was centrifuged for 10 minutes at 3,000 x g and the supernatant was used for the analysis of antioxidant activity and total phenolics content.

Samples $(0.5 \mathrm{~g})$ of the dried chip-type beet products after being ground to a fine powder (particle size $<0.5 \mathrm{~mm}$ ), were also extracted with $15 \mathrm{~mL}$ of chilled aqueous methanol (methanol:water, 80:20 v/v) using ultrasonic treatment (Unique equipment USC-1400) for 30 minutes at room temperature. The mixture obtained was centrifuged for 10 minutes at 3,000 x g and the supernatant was used for the analysis of antioxidant activity and total phenolics content.

\section{Determination of total phenolic compounds}

The total phenolic compounds content was determined spectrophotometrically (Hewlett-Packard 8452 A, Florianópolis, Brazil) according to the Folin-Ciocalteau procedure (SINGLETON; ROSSI, 1965), and an absorbance at $765 \mathrm{~nm}$ was measured. In this method, the phosphomolybdic phosphotungstic acid is reduced in basic medium in order to oxidize the phenolic compounds, resulting in the blue color oxides of tungsten $\left(\mathrm{W}_{8} \mathrm{O}_{23}\right)$ and molybdenum $\left(\mathrm{Mo}_{8} \mathrm{O}_{23}\right)$ (KUSKOSKI et al., 2006). The total phenolics content was expressed as 'milligrams of gallic acid equivalent per 100 gram of 
dry material (mg GAE. $100 \mathrm{~g}^{-1}$, dwb)' of the beet product (dried, canned or raw). The beet extracts were analyzed in duplicate.

\section{Determination of antioxidant activity - ABTS method}

The ABTS (2,2'-azino-bis-3-ethylbenzothiazolin-6sulfonic acid) method was carried out as described by Re et al. (1999). The $\mathrm{ABTS}^{\bullet+}$ radical was generated by mixing $2.45 \mathrm{mM}$ of potassium persulfate solution with $7 \mathrm{mM}$ of aqueous ABTS solution, followed by incubation in the dark at room temperature for 16 hours. Absorbance at $734 \mathrm{~nm}$ was measured (Hewlett-Packard model 8452 A) 7 minutes after the addition of the beet sample extract. The antioxidant activity was expressed, as given in Rice-Evans, Miller and Paganga (1996), in ' $\mu \mathrm{Mol}$ of TEAC (Trolox equivalent to the antioxidant activity). $100 \mathrm{~g} \mathrm{~g}^{-1}$ of dry weight' of the beet product (dried, canned or raw). The beet extracts were analyzed in duplicate.

\subsection{Statistical analysis}

The results were submitted to analysis of variance and when a statistical significance was detected, they were compared using the LSD test (low statistical difference). Level of significance was set at $\mathrm{p} \leq 0.05$. The correlation coefficient ( $r$ ) for the relation between the antioxidant activity (ABTS) and the total phenolics content variables was determined.

\section{Results and discussion}

The different drying conditions (treatments), applied to the fresh raw beets to obtain the chip-type dried beet products, affected in distinct ways the total antioxidant capacity (Figure 1) and the total phenolic compounds content (Figure 2) in the processed products obtained.

Treatments that used mild conditions throughout the drying processes, $80{ }^{\circ} \mathrm{C} / 6$ hours and $100+70{ }^{\circ} \mathrm{C} / 6$ hours, reduced significantly $(\mathrm{p} \leq 0.05)$ the antioxidant activity value ( $\mu$ Mol TEAC. $100 \mathrm{~g}^{-1}, \mathrm{dwb}$ ) from $4430.88 \pm 279.11$ in raw beet to values of $3555.39 \pm 362.16$ and $4065.21 \pm 320.52$ in the processed products (beet chips), respectively. In contrast, products treated using other mild drying conditions did not differ significantly ( $\mathrm{p}>0.05)$ from the raw beet control $(4430.88 \pm 279.11)$, as the $70{ }^{\circ} \mathrm{C} / 7$ hours $(4721.959 \pm 95.54)$ and $100+80^{\circ} \mathrm{C} / 6$ hours $(4604.52 \pm 304.95)$ treatments.

The treatments that used comparatively the highest temperatures during the drying processes, $100+90^{\circ} \mathrm{C} / 5.6$ hours and $90^{\circ} \mathrm{C} / 6$ hours, resulted in significantly $(\mathrm{p} \leq 0.05)$ higher values for the antioxidant activity ( $\mu$ Mol TEAC. $100 \mathrm{~g}^{-1}, \mathrm{dwb}$ ) of the dried beet products, $4996.65 \pm 117.70$ and $5036.97 \pm 42.55$ (Figure 1), respectively. These treatments did not differ significantly $(\mathrm{p}>0.05)$ from each other. The $70{ }^{\circ} \mathrm{C} / 7$ hours treatment (Figure 1), with the longest time and low temperature used throughout the drying process, also resulted, surprisingly, in an antioxidant activity value ( $\mu$ Mol TEAC. $\left.100 \mathrm{~g}^{-1}, \mathrm{dwb}\right)$ of $4721.95 \pm 95.54$ for the beet chip-type products, which was not significantly $(\mathrm{p}>0.05)$ different compared to the $90^{\circ} \mathrm{C} / 6$ hours (5036.97 \pm 42.55$)$ and $100+90^{\circ} \mathrm{C} / 5.6$ hours $(4996.65 \pm 117.70)$ treatments.
In relation to the total phenolics content, $\mathrm{mg}$ GAE $100 \mathrm{~g}^{-1} \mathrm{dwb}$ (Figure 2), the $90{ }^{\circ} \mathrm{C} / 6$ hours and $100+90{ }^{\circ} \mathrm{C} / 5.6$ hours treatments, as in the case of the antioxidant activity, showed the highest values (mg GAE.100 $\mathrm{g}^{-1}$, dwb): $809.19 \pm 68.88$ and $872.12 \pm 83.65$, respectively, and they did not differ significantly ( $p>0.05$ ) from each other. The $70^{\circ} \mathrm{C} / 7$ hours treatment also resulted in a total phenolics content (mg GAE.100 g ${ }^{-1}$, dwb) significantly $(\mathrm{p} \leq 0.05)$ higher $(717.32 \pm 37.25)$ than the raw beet control ( $588.40 \pm 75.96$ ), while the $80^{\circ} \mathrm{C} / 6$ hours treatment showed a significantly $(\mathrm{p} \leq 0.05)$ lower value $(469.49 \pm 54.97)$. Furthermore, two other treatments, $100+70{ }^{\circ} \mathrm{C} / 6$ hours and $100+80{ }^{\circ} \mathrm{C} / 6$ hours, which resulted in total phenolics content values (mg GAE.100 $\mathrm{g}^{-1} \mathrm{dwb}$ ) of $543.12 \pm 63.63$ and $660.06 \pm 69.902$, respectively, did not differ significantly ( $p>0.05)$ compared to the raw beet control (588.40 \pm 75.96$)$.

For all processing treatments using comparatively mild drying conditions $\left(70{ }^{\circ} \mathrm{C} / 7\right.$ hours; $80{ }^{\circ} \mathrm{C} / 6$ hours; $100+70{ }^{\circ} \mathrm{C} / 6$ hours or $100+80^{\circ} \mathrm{C} / 6$ hours), the antioxidant activities of the beet chip-type products were dependent on the total phenolics content, with strong positive correlations of $r$ equals $0.8294,0.8909,0.9829$ and 0.9216 , respectively. However, for the drying process using high temperatures $\left(100{ }^{\circ} \mathrm{C}\right.$ or $\left.90^{\circ} \mathrm{C}\right)$, the antioxidant activity was also dependent on other factors, not only on the increase in the total phenolics content. One product had a strong negative correlation $(\mathrm{r}=-0.7737)$ and the other showed a very weak correlation, for drying conditions of $90^{\circ} \mathrm{C} / 6$ hours and $100+90^{\circ} \mathrm{C} / 5.6$ hours, respectively.

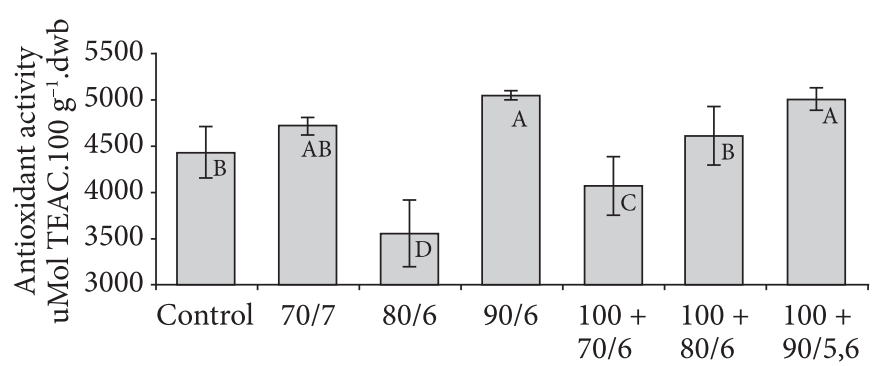

Treatments: drying conditions $\left({ }^{\circ} \mathrm{C} /{ }_{-} \mathrm{h}\right)$ and raw beetroot (control)

Figure 1. Antioxidant activity in dried beet products and raw beet (control). Values are means \pm SEM (Standard Error of the Mean), $\mathrm{n}=5$; means with similar letters do not differ $(\mathrm{p}>0.05)$ according to the LSD test.

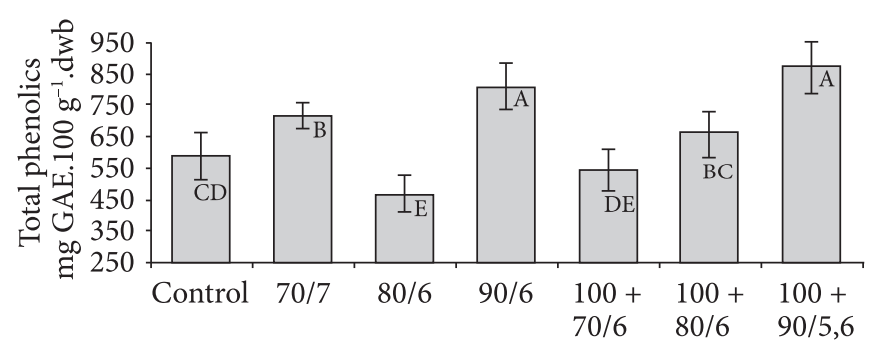

Treatments: drying conditions $\left({ }^{\circ} \mathrm{C} / \_\mathrm{h}\right)$ and raw beetroot (control)

Figure 2. Total phenolics in dried beet products and raw beet (control). Values are means \pm SEM (Standard Error of the Mean), $n=5$; means with similar letters do not differ $(\mathrm{p}>0.05)$ according to the LSD test. 
The different processing procedures (treatments) also affected differently the total antioxidant capacity, $\mu \mathrm{Mol}$ TEAC. $100 \mathrm{~g}^{-1} \mathrm{dwb}$, (Figure 3) and the total phenolic compounds content, mg GAE.100 $\mathrm{g}^{-1} \mathrm{dwb}$, (Figure 4) in the canned beet products.

Among the canned products of the treatments carried out at five different levels of $\mathrm{pH}(4.2,4.1,4.0,3.9,3.8)$, there were no significant $(\mathrm{p}>0.05)$ differences in the antioxidant activity, $\mu$ Mol TEAC. $100 \mathrm{~g} \mathrm{~g}^{-1} \mathrm{dwb}$ (Figure 3), for each acid used in the canned products: citric acid, lactic acid, acetic acid and vinegar from ethyl alcohol. Compared to the raw beet control $(4566.04 \pm 313.70)$, canned products prepared with vinegar
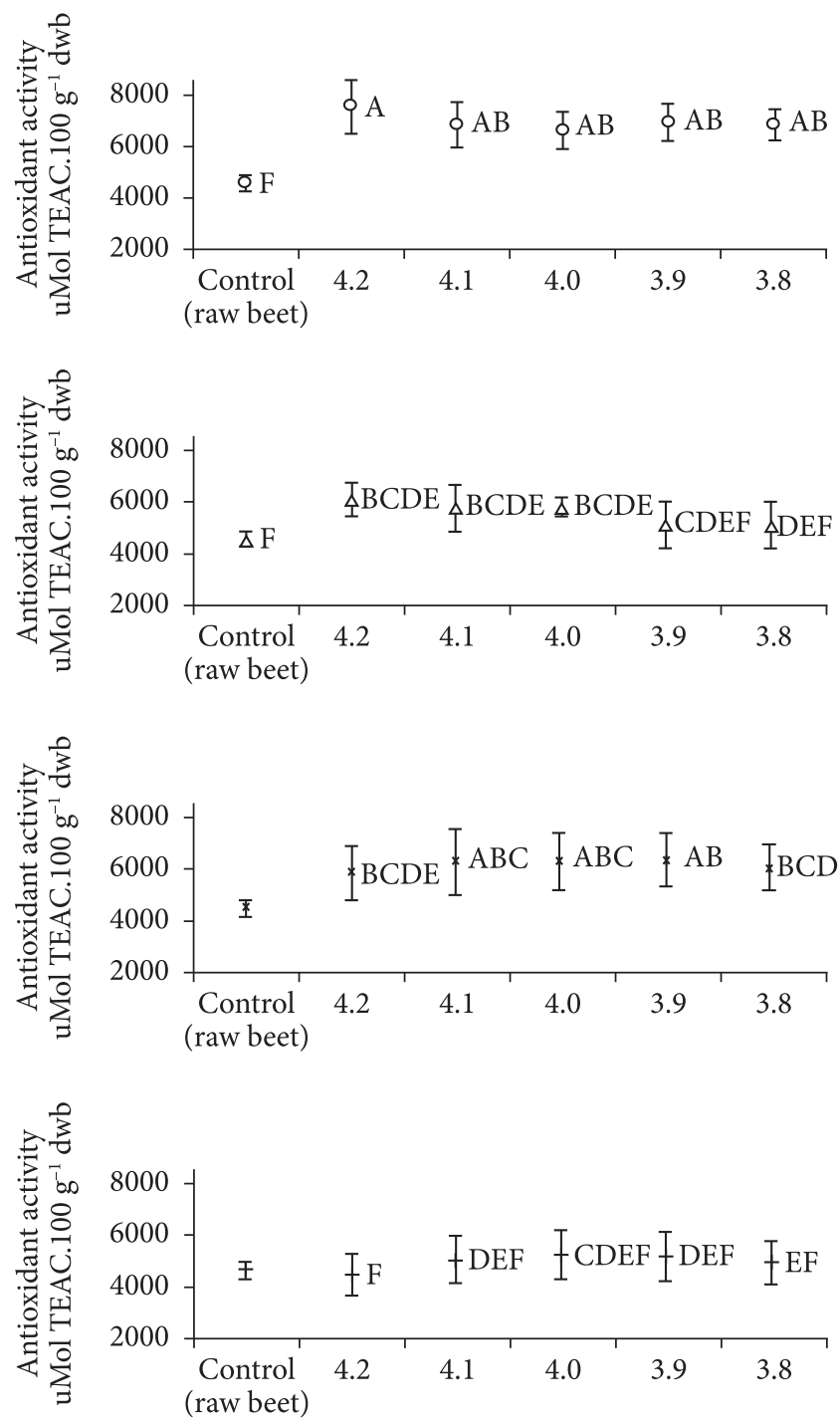

Treatments: control and $\mathrm{pH}$ of canned

- Citric acid $\Delta$ Lactic acid * Acetic acid

+ Vinegar (from ethyl alcohol)

Figure 3. Antioxidant activity ( $\mu \mathrm{Mol} \mathrm{TEAC.} 100 \mathrm{~g}^{-1} \mathrm{dwb}$ ) in canned beet products and raw beet (control). Values are means \pm SEM (Standard Error of the Mean), $\mathrm{n}=4$; means with similar letters do not differ ( $p>0.05)$ according to the LSD test. showed no significant $(\mathrm{p}>0.05)$ change in the antioxidant activity (4395.96 \pm 785.63 to $5148.23 \pm 925.00)$; however, with citric acid (6653.01 \pm 723.99 to $7531.19 \pm 1051.20)$ and acetic acid $(5957.47 \pm 1060.43$ to $6453.63 \pm 1056.05)$ there was significantly $(\mathrm{p} \leq 0.05)$ increased activity; and in the case of lactic acid at low $\mathrm{pH}(3.9)(5126.78 \pm 880.16)$ or $3.8(5088.97 \pm 881.22)$ there was no significant $(\mathrm{p}>0.05)$ change, while at high $\mathrm{pH}$ $(4.2,4.1$ or 4.0$)(5752.12 \pm 924.91$ to $6055.76 \pm 659.24)$, there was a significant $(\mathrm{p} \leq 0.05)$ increase in the antioxidant activity of the canned products.

The total phenolics content, mg GAE.100 $\mathrm{g}^{-1} \mathrm{dwb}$ (Figure 4), of the raw beet control $(628.36 \pm 76.06)$ did not differ significantly from that of some canned products, such as the canned products of the treatments using lactic acid at $\mathrm{pH} 4.1$ (687.36 \pm 34.75$), \mathrm{pH} 3.9(637.48 \pm 33.01)$ or $\mathrm{pH} 3.8$ (580.47 \pm 34.88$)$; also, those using vinegar from ethyl alcohol at $\mathrm{pH} 4.2(591.16 \pm 34.67)$ or $\mathrm{pH} 4.1(658.58 \pm 8.62)$. For the other treatments, the total phenolics content increased
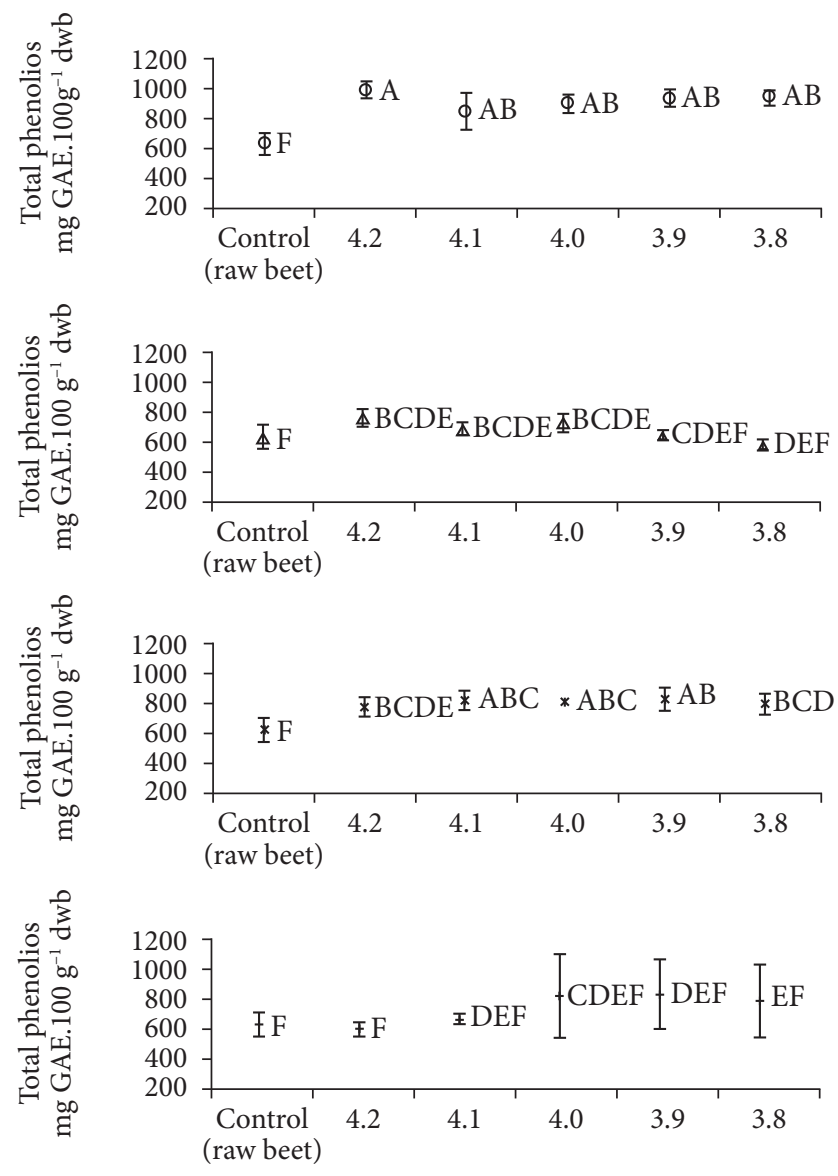

Treatments: control and $\mathrm{pH}$ of canned

$$
\begin{aligned}
& \text { - Citric acid } \Delta \text { Lactic acid * Acetic acid } \\
& + \text { Vinegar (from ethyl alcohol) }
\end{aligned}
$$

Figure 4. Total phenolics (mg GAE. $100 \mathrm{~g}^{-1} \mathrm{dwb}$ ) in canned beet products and raw beet (control). Values are means \pm SEM (Standard Error of the Mean), $\mathrm{n}=4$; means with similar letters do not differ ( $p>0.05$ ) according to the LSD test. 
significantly $(\mathrm{p} \leq 0.05)$ in the canned products after processing (723.01 \pm 40.44 to $984.26 \pm 36.81)$, compared to the control (628.36 \pm 76.06$)$.

In the canned beet products, the antioxidant activity of some products was dependent strongly on the total phenolic content. Thus, for the canned products in vinegar, the antioxidant activity varied as a function of the total phenolic content, and there were strong positive correlations ( $\mathrm{r}$ values of 0.7173 to 0.8607 ) for every $\mathrm{pH}$ value tested (4.2 to 3.8 ). In the canned products prepared with the other acids, there were also strong positive correlations for some $\mathrm{pH}$ values, such as, in canned products containing lactic acid at $\mathrm{pH} 4.1(\mathrm{r}=0.9308)$ and $\mathrm{pH} 3.9$ $(\mathrm{r}=0.9825)$, and citric acid at $\mathrm{pH} 3.8(\mathrm{r}=0.7238)$. However, some canned products showed strong negative correlations, such as those with lactic acid at $\mathrm{pH} 4.0(\mathrm{r}=-0.9530)$, and acetic acid at $\mathrm{pH} 4.2(\mathrm{r}=-0.8462)$ and $\mathrm{pH} 4.1(\mathrm{r}=-0.9945)$. The other canned products presented weak correlations and their antioxidant activity was also dependent on other factors, not only on the phenolic compounds contents.

Previous studies verified the effect of different heat processing techniques on the total phenolic content and the antioxidant potential of food products (BOATENG et al., 2008; PADDA; PICHA, 2008). According to Boateng et al. (2008), in dry beans, the total phenolics were lower after soaking, but increased after toasting. In contrast, the heat processing decreased the phenolic content and antioxidant capacity of sweet potato cv. 'Beauregard' raw skin tissue (PADDA; PICHA, 2008). Total phenolic content in raw sweet potato skin (1770.0 mg CAE. $100 \mathrm{~g}^{-1}$, dwb) tissue was reduced by $37 \%$ after boiling, $42 \%$ after microwaving, and 55\% after conventional oven baking. Parallel to the change in total phenolic content, all types of heat processing resulted in a significant loss of antioxidant capacity in raw skin (2290.0 mg TE. $100 \mathrm{~g}^{-1}$, dwb) tissue. Heat processing resulted in no significant change in total phenolic content and antioxidant potential in the cortex and pith tissue. A strong correlation $(r=0.98)$ was found between total phenolic content and antioxidant capacity in sweet potato root tissue. According to the authors, heating may disrupt the intracellular separation of the phenolic acids and oxidative enzymes (polyphenoloxidases), resulting in degradation of the phenolic acids.

Madrau et al. (2008) evaluated the effects of hot air $\left(55^{\circ} \mathrm{C}\right.$; $75^{\circ} \mathrm{C}$ ) drying on polyphenolic content and antioxidant activity of two apricot cultivars. The antioxidant capacity increased significantly in the Cafona cultivar fruits as a consequence of increasing drying temperature $\left(55^{\circ} \mathrm{C}\right.$ and $\left.75^{\circ} \mathrm{C}\right)$, while the values did not change in the Pelese apricots. The sum of the polyphenols drastically decreased, thus the assay should have give opposite results, especially on Cafona apricots, where the antioxidant values were four times higher in fruits dried at $75{ }^{\circ} \mathrm{C}$. The authors concluded that the higher drying temperature gave a better product from the antioxidant and polyphenol contents point of view. Phenols degradation during hot air drying did not always result in the same effects. More than one reason can explain the behaviors for the results in the current study. Differences between treatments in terms of the subsequent antioxidant potential, in drying (Figure 1) and in canned processing (Figure 3), may arise from the phenomena of enzymatic action and/or physicochemical action, which are highly dependent on temperature as well as on levels of water, oxygen, and natural compounds such as the beet phenolics constituents.

In drying treatments using temperatures of $100^{\circ} \mathrm{C}+90^{\circ} \mathrm{C}$ or $90{ }^{\circ} \mathrm{C}$ alone for the whole process (Figure 1), the enzyme systems of the beet - such as polyphenoloxidases, which transform the phenolic compounds into quinones - appear to have been inactivated. Thus, the greater antioxidant capacity of the dried products obtained by treatments at both $100+90{ }^{\circ} \mathrm{C} / 5.6$ hours and $90{ }^{\circ} \mathrm{C} / 6$ hours, compared to the raw beet control, could be due to the generation of new units of bioactive phenolic compounds, resulting mainly from the action of heat on larger phenolic natural compounds of beet. The disruption of the cell wall through heating or the breakdown of insoluble phenolic compounds could have led to better extractability of these compounds. According to Dewanto, Wu and Liu (2002), thermal processing may release more bound phenolic acids from the breakdown of cellular constituents in sweet corn. The authors also reported an increase in antioxidant activity following thermal treatments of sweet corn. The highest antioxidant properties during heating may also be due to the formation of mailliard products such as hydroxymethylfurfuraldehyde (HMF), which produces high antioxidant activity (SIDDHURAJU, 2006; DUENAS et al., 2005).

On the other hand, a residual enzyme action on the natural phenolic compounds with the formation of quinones may have led to the lower values for the antioxidant activity of dried products in the treatments of $100+70{ }^{\circ} \mathrm{C} / 6$ hours or $80^{\circ} \mathrm{C} / 6$ hours (Figure 1). In addition, the lower temperature applied one hour after the start of the drying was not, apparently, sufficient to generate new units of bioactive compounds in these treatments. In other treatments using mild drying conditions $\left(70^{\circ} \mathrm{C} / 7\right.$ hours; $100+80^{\circ} \mathrm{C} / 6$ hours), there was no generation of new units of bioactive compounds attributed to the application of heat. Furthermore, since these conditions were not sufficient to completely inactivate the polyphenoloxidases in the raw beet, a little oxidant action of these enzymes with formation of quinones remained, resulting in a loss of the antioxidant potential of these dried products. Moreover, the action of hydrolyzing enzymes and those which act on complex phenolic units, generating new smaller bioactive phenolic units can not be disregarded. This may explain why the antioxidant potential of the dried products prepared using these treatments did not differ from the control (raw beet).

In canned beet products, the presence of an organic acid in water, along with the anaerobic salinization and the action of heat (heat treatment), may have favored the degradation of the natural phenolic compounds, or other changes at the molecular level of the natural phenolic compounds, as well as at other constituents of the raw beet. This would lead to increased antioxidant potential in some of the canned products compared to the control (raw beet). Therefore, this may be the reason for the higher values obtained for the antioxidant activity (Figure 3 ) in the canned products prepared with treatments using citric 
acid or acetic acid for all $\mathrm{pH}$ values studied (4.2, 4.1, 4.0, 3.9, 3.8), or lactic acid at $\mathrm{pH} 4.2,4.1$ and 4.0.

\section{Conclusions}

Drying at high temperatures $\left(100+90{ }^{\circ} \mathrm{C} / 5.6\right.$ hours; $90{ }^{\circ} \mathrm{C} / 6$ hours) increased the antioxidant activity of processed products, whereas mild drying conditions decreased it ( $80{ }^{\circ} \mathrm{C} / 6$ hours; $100+70{ }^{\circ} \mathrm{C} / 6$ hours) or had no effect on it $\left(70{ }^{\circ} \mathrm{C} / 7\right.$ hours; $100+80{ }^{\circ} \mathrm{C} / 6$ hours $)$.

The use of different $\mathrm{pH}$ values (4.2 to 3.8) in the preparation of canned beet products did not affect the antioxidant activity for any of the acids used.

Some methods of drying and acidic canned processing influenced the antioxidant potential (ABTS) in the processed products, and this was also dependent on changes in the total phenolics content.

\section{References}

APARICIO-FERNANDEZ, X. et al. Characterization of polyphenolics in the seed coat of black jamapa bean (Phaseolus vulgaris L. ). Journal of the Agricultural and Foof Chemistry, v. 53, n. 11, p. 4615-4622, 2005. http://dx.doi.org/10.1021/jf047802o

ASSOCIATION OF OFFICIAL ANALYTICAL CHEMISTS - AOAC. Official Methods of Analysis. 16th ed. Arlington: AOAC, 1995. $1141 \mathrm{p}$.

BOATENG, J. et al. Effect of processing on antioxidant contents in selected dry beans (Phaseolus spp. L. ). Food Science and Technology (LWT), v. 41, p. 1541-1547, 2008.

DEWANTO, V.; WU, X.; LIU, R. H. Processed sweet corn has higher antioxidant activity. Journal of Agricultural and food Chemistry, v. 50, n. 17, p. 4959-4964, 2002. http://dx.doi.org/10.1021/jf0255937

DUENAS, M. et al. Bioactive phenolic compounds of cowpeas (Vigna sinensis L. ). Modifications by fermentation with natural microflora and with Lactobacillus plantarum ATCC 14917. Journal of the Science of Food and Agriculture, v. 85, p. 297-304, 2005. http:// dx.doi.org/10.1002/jsfa.1924

GARCÍA-ALONSO, M. et al. evaluation of the antioxidant properties of fruits. Food Chemistry, v. 84, p. 13-18, 2004.

KAUR, C.; KAPOOR, H. C. Antioxidants in fruits and vegetables - the millennium's health. International Journal of Food Science \& Technology, v. 36, n. 7, p. 703-725, 2001. http://dx.doi.org/10.1046/ j.1365-2621.2001.00513.x

KIM, D. O.; JEONG, S. W.; LEE, C. Y. Antioxidant capacity of phenolic phytochemicals from various cultivars of plums. Food Chemistry, v. 81, n. 3, p. 321-326, 2003. http://dx.doi.org/10.1016/S03088146(02)00423-5

KUSKOSKI, M. E. et al. frutas tropicais silvestres e polpas de frutas congeladas: atividade antioxidante, polifenóis e antocianinas. Ciência Rural, v. 36, n. 4, p. 1283-1287, 2006.

LAJOLO, F. M. Alimentos funcionais: uma visão geral. In: DE ANGELIS, R. C. (Ed. ). A importância dos alimentos vegetais na proteção da saúde: fisiologia da nutrição protetora e preventiva de enfermidades degenerativas. São Paulo: Atheneu, 2005. p. 175-181.

MADRAU, M. A. et al. Effect of drying temperature on polyphenolic content and antioxidant activity of apricots. European Food Research and Technology, v. 228, n. 3. p. 441-448, 2008. http:// dx.doi.org/10.1007/s00217-008-0951-6

MORNEMENT, J. Just beet. Fresh Produce Journal, v. 5, p. 24-25, 2002.
MOYER, R. A. et al. Anthocyanins, Phenolics, and Antioxidant Capacity in Diverse Small Fruits: Vaccinium, Rubus, and Ribes. Journal of the Agriculture and Food Chemistry, v. 50, p. 519-525, 2002. http://dx.doi.org/10.1021/jf011062r

NILSON, T. Studies into the pigments in beetroot (Beta vulgaris L. ssp. vulgaris var. rubra L. ). Lantbrukhogskolans Annaler, v. 36, n. 1, p. 179-219, 1970.

PADDA, M. S.; PICHA, D. H. Phenolic composition and antioxidant capacity of different heat-processed forms of sweetpotato cv. 'Beauregard'. International Journal of Food Science and Techonology, v. 43, p. 1404-1409, 2008. http://dx.doi.org/10.1111/ j.1365-2621.2007.01663.x

PRIOR, R. L. et al. Antioxidant capacity as influenced by total phenolic and anthocyanin content, maturity, and variety of Vaccinium species. Journal of the Agricultural and Food Chemistry, v. 46, p. 2686-2693, 1998. http://dx.doi.org/10.1021/jf980145d

RE, R. et al. Antioxidant activity applying an improved ABTS radical cation descolorization assay. Free Radical Biological Medicine, v. 26, p. 1231-1237, 1999. http://dx.doi.org/10.1016/S08915849(98)00315-3

REY, A. I. et al. Use of natural food/plant extracts: cloudberry (Rubus Chamaemorus), beetroot (Beta vulgaris "vulgaris") or willow herb (Epilobium angustifolium) to reduce oxidation of cooked pork patties. Food Science and Technology, v. 38, p. 363-370, 2005.

RICE-EVANS, C. A.; MILLER, N. J.; PAGANGA, G. Structure antioxidant activity relationships of flavonoids and phenolic acids. Free Radical Biological Medicine, v. 20, p. 933-956, 1996. http:// dx.doi.org/10.1016/0891-5849(95)02227-9

ROESLER, R. et al. Atividade antioxidante de frutos do cerrado. Ciência e Tecnologia de Alimentos, v. 27, n. 1, p. 53-60, 2007.

SCALZO, J. et al. Plant genotype affects total antioxidant capacity and phenolic contents in fruit. Nutrition, v. 21, p. 207-213, 2005. http:// dx.doi.org/10.1016/j.nut.2004.03.025

SIDDHURAJU, P. The antioxidant activity and free radicalscavenging capacity of phenolics of raw and dry heated moth bean (Vigna aconitifolia) (Jacq. ) Marechal seed extracts. Food Chemistry, v. 99, n. 1, p. 149-157, 2006. http://dx.doi.org/10.1016/j. foodchem.2005.07.029

SINGLETON, V. L.; ROSSI, J. A. Colorimetry of total phenolics with phosphomolybdic-phosphotungstic acid reagents. American Journal of Enology and Viticulture, v. 16, p. 144-158, 1965.

TROUNG, V. D. et al. Phenolic compounds and antioxidant capacity of commercial sweetpotato cultivars. In: IFT ANNUAL MEETING, 2004, Las Vegas. Proceedings... Las Vegas, 2004. n. 49F-27.

VALI, L. et al. Liver-protecting effects of table beet (Beta vulgaris var. rubra) during ischemia-reperfusion. Nutrition, v. 23, n. 2, p. 172-178, 2007. http://dx.doi.org/10.1016/j.nut.2006.11.004

YANG, J.; GUO, J.; YUAN, J. In vitro antioxidant properties of rutin. Food Science and Technology, v. 41, p. 1060-1066, 2008.

YANG, C. S. et al. Inhibition of carcinogenesis by dietary polyphenolic compounds. Annual Review of Nutrition, v. 21, p. 381-406, 2001. http://dx.doi.org/10.1146/annurev.nutr.21.1.381

WANG, S. Y.; ZHENG, W.; GALLETTA, G. J. Cultural system affects fruit quality and antioxidant capacity in strawberries. Journal of the Agricultural and Food Chemistry, v. 50, p. 6534-6542, 2002. http://dx.doi.org/10.1021/jf020614i

WU, X. et al. Lipophilic and Hydrophilic Antioxidant Capacities of Common Foods in the United States. Journal of the Agricultural and Food Chemistry, v. 52, p. 4026-4037, 2004. http://dx.doi. org/10.1021/jf049696w 